\section{SOI: $1.1 /$ TAS DOI: $10.15863 /$ TAS International Scientific Journal Theoretical \& Applied Science}

\section{Adhamjon Askarjonovich Mirzachaev}

Researcher

"Spirituality and religion studies" chair The Mirzo Ulugbek National University of Uzbekistan conference_2012@list.ru

Year: $2015 \quad$ Issue: $08 \quad$ Volume: 28

Published: $30.08 .2015 \quad$ http://T-Science.org

SECTION 30. Philosophy.

\title{
THE CONCEPT OF THE SPIRITUAL CULTURE OF THE PERSON
}

Abstract: In this article provides a brief historical analysis of the concepts of «spirituality», «spiritual culture», "spiritual culture of personality», the views of thinkers of the East and the West on this question. It also examines the place and importance of spiritual culture in the education of harmoniously and comprehensively developed personality.

Key words: person, society, spirituality, spiritual culture, harmoniously developed personality, education, material culture, thinkers of the Central Asia.

Language: English

Citation: Mirzachaev AA (2015) THE CONCEPT OF THE SPIRITUAL CULTURE OF THE PERSON. ISJ Theoretical \& Applied Science 08 (28): 112-114.

Soi: http://s-o-i.org/1.1/TAS-08-28-20 Doi: crossef http://dx.doi.org/10.15863/TAS.2015.08.28.20

The analysis of the problems of spiritual life of society, questions related to its culture, largely depend on the characteristics approach to the definition of the culture. Today there are many definitions of this concept. This diversity is due primarily to the objective ambiguity of culture. "The richer to be determined subject," wrote Hegel, i.e. the more different parties it is considered, moreover, are different definitions given to it" [1].

Each of the sciences that study the questions of culture, based on their subject of study, reveals it sides and relations that fall within the range of consideration of this science. The increasing role of culture in society, the progress made in scientific thought is largely responsible for the increased attention of social scientists to theoretical and methodological questions of spiritual culture.

The history of the philosophical development of theoretical problems of culture dates back to the XVIII - XIX centuries. Schelling, Hegel, Schopenhauer, Herder and many other philosophers have considered culture in the mainstream of classical idealism, where the basis is, as written by other scientists, was taken "only one type of labor, it is abstract and spiritual work" [3].

The formation of the spiritual world comprehensively, harmoniously developed personality involves the use of complex and system approaches in the process of education. A comprehensive and systematic impact on all factors of formation of spiritual culture from socioeconomic relations to ambient educate the moral- psychological atmosphere is necessary in the process of educational orientation of students.

The creation of a culture of personality, which includes the effect of both objective and subjective factors that interact with each other is not only the result of a conscious and focused on it impact, but also spontaneously, under the influence of objective conditions of people's lives.

The objective conditions for the formation of the younger generation is not always enough to accurately and fully reflect the features of its age, professional and individual - typological nature. Only organic link between the effects of objective conditions and the subjective factor can provide purposeful formation of the spiritual world of the personality according to a given pattern.

This explains the importance of a comprehensive, systemic nature of the formation of the spiritual culture of the students. This process must strictly comply with the requirements of social life, constituting an integrated system.

Speaking qualitative indicator of the spiritual life of society, spiritual culture in its structure identical to the structure of the spiritual realm of public life, which as a system is a unity of components such as spiritual activities, spiritual needs, spiritual use, social institutions, and spiritual relationships and communication.

One of the advantages of the system approach is that it gives the opportunity to explore the unity and interconnection of all components of spiritual culture, to analyze the processes underlying the 
formation of the spiritual world of the personality in the conditions of the country, reforms in all spheres of social life, to reveal the regularities of the formation of harmonious development and socially active person.

The full development of personality, formation of aesthetic, environmental, moral and creative elements of spiritual culture among students is one of the tasks of educational work in various educational institutions. And the task of teachers - to educate future young workers and specialists so that as they were leaving institute, they were able to bring beauty in life, in work, in relationships of people. The main elements of spiritual culture cannot be formed separately from each other. They are closely interrelated.

The analysis of the theoretical and practical basis of forming cultural identity in the years of independence of the Republic of Uzbekistan has been the subject of many researches of scientists. Modern researches are paying considerable attention to the concept of spiritual culture, its essence and content. Culture and spiritual culture in particular, is organizing the content elements of political culture, moral culture, economic culture, legal culture, aesthetic culture. These elements of culture are formed and developed together with the enrichment of the life of the person and society. In turn, the rise of cultural elements enriched by close interrelation of socialization in the process of personality development. The focus objectives of the personality will be known in the future, the formation of beliefs in the worldview of the person. Each person in society has their own unique beliefs, views on which is based the formation of a humanistic type of perfection of spiritual culture. Thus, the identity formed national, religious and human values such as humanity, patriotism, interethnic harmony, religious tolerance, political consciousness. The formation of the spiritual culture of the person, its enrichment socialization, continues to become more complex and the value of each social system, in a certain political influence. For example, during the former Soviet system of spiritual culture of personality was filled with Communist content and subordinated to the ideas of collectivism, equality, and national and religious values is ignored. In these circumstances, the spiritual culture of a person is not only developed, but also limited to spiritual freedom.

The question of spiritual culture of the person appears to be wide-ranging philosophical category and therefore all its processes to describe is not so easy. The formation of the person's spirituality, particularly enriched at the expense of objective and subjective factors inherent in the development of human history. This is socio-economic, spiritual and moral way of development of society. In particular, this historical process of national and religious values form the basis of spirituality. As we know, every man that cometh into the world, from the beginning to the end of their life absorbs the specific features of their region, customs, traditions, rules and conditions of individual and social life, all these values are of great importance for man and mankind. The person always feels the impact of their educational orientation [1]. Also "the historical formation of these values will have a value for all the phenomena of man and mankind" [2].

In each person the formation of spirituality is based on his material and spiritual needs. As material and spiritual needs filled with certain content and have an obvious difference compared with each other, which can be shown. For example, spiritual need, according to most scientists, based on education, enriched by heredity (writers, painters, sculptors and owners of other professions have such abilities). However, in our view, the existence of individual abilities in each person produces spiritual culture of a person and requires tireless work, continuous improvement, hereditary and acquired abilities. The subject of this typical process of life not only customized, but also along with this individualization in a sense generalizes [3].

A material need also goes through the stage of formation in the development of personality. A material need for each person is living conditions, the quality and standard of living, environment, clothes, in general, all that is necessary for material wellbeing. All this is achieved through the purchase and sale, whereby all which is acquired. This state, on the one hand, is a certain life for each person, and on the other hand, creates in people, not only religious values, but also manifests in adherence to generally accepted laws prevailing in the society.

Theoretical bases of formation of spirituality of the person laid such prominent scientists and philosophers as Socrates, Plato, Aristotle, Kant [4] and others. These scientists in their views considered the problem of the relation between the person and society or place of the person in society. In this aspect of consideration of the personality of the focus was on harmonizing individual and social in the individual, the spiritual with the material. Especially the problem of spirituality in the person becoming fundamental in ancient philosophy since the age of Socrates. Only Socrates linked vital necessity of spiritual culture of personality and its continuous improvement over the whole life of the person. Modern philosophers and researchers of the problem of spiritual culture of a person basically updates the views of the ancient philosophers and adapt them to given conditions.

Scientific understanding of the person in its internal formation also has a system of religious philosophy. If in the philosophy of the ancient period the focus was on the spiritual principle person itself, in the Medieval philosophy takes a turn for the supernatural spiritual beginning. For example, in the 
teachings of Christianity spirituality is understood as a synonym for spirituality supernatural, "individual substance", specialities of the mind, intangible spirit as part of God in man.

The philosopher of the New age R.Descartes suggested a dualistic beginning in man. According to the German philosopher Immanuel Kant is the spiritual principle in man distinguishes us from the animal kingdom [5]. English philosopher John.Lock emphasized the ability "to think intelligently" in man, as a manifestation of spiritual culture [6]

Also as in the West, in the East the idea of spiritual culture was the center of attention of Oriental scientists. In particular, scientists of the Central Asia have devoted considerable space in their works to this phenomenon. Initially, the concept of spiritual culture was contained in the sacred books of the peoples of this region - Avesto and the Orkhun inscription [7].

The Eastern thinkers Abu Nasr al-Farabi, Abulqosim Firdawsi, Abu Abdulla Horazmi, Abu Ali Ibn Sina, Abu Rayhon Beruniy, Abu Abdulla
Rudaki, Yusuf Hos Hojib, Yusuf Hamadani, Keykavus, Akhmad Yugnaki arr also known for their researches in the field of spiritual culture. In X-XV centuries, the study of spiritual culture was continued efforts of Akhmad Yassaviy, Sheikh Najmiddin Kubro, Amir Temur, Alisher Navoi, Zahiriddin Muhammad Babur and other thinkers and political figures.

According to the modern researcher of spiritual culture Eileen Barker, spirituality is different from religion because the source of the latter is the external world in the form of regulations and traditions, while a source of spirituality is an internal experience of the person [8]. We can also say that "spirituality is the ability to translate foreign supermarket of being in the inner universe of a person on an ethical basis, the ability to create the inner peace that ensures true submodeling of man, his freedom before ever-changing situations. Spirituality is, ultimately, leads to a sort of semantic cosmogony, the connection image of the world with the moral law of the individual" [9].

\section{References:}

1. Ochilova BM (2005) Azhdodlar merosiga ihlosmandlik va shahs ma\#navij-ahloқij kamoloti: Dis...avtoref.fals. fan. dokt.Toshkent: ЎzMU, 2005.-pp.18.

2. (1998) Mustaқillik izoxli ilmij-ommabop luғat.Toshkent: Shark, 1998. - pp.280.

3. (1998) Novejshij filosofskij slovar'. Sost. A.A.Gricalov. -Minsk. Izd.V.M.Skakun. 1998. pp.476.

4. (1976) Aristotel'. Metafizika. Sochinenija. T.4. - Moscow: 1976.

5. Kant I (1965) Sochinenija. T.4. - Moscow: 1965.

6. Kant I (1965) Soch.4. Ch.2. - Moscow: 1965. pp.132.
7. Dzh.Lokk (1960) Izbr. filosofskie proizvedenija. T.1. - Moscow: 1960. - pp.338.

8. (2001) «Avesto» va uning insonijat taraққijotidagi y̆rni. -Toshkent: Fan, 2001.

9. Raxmonov N (1987) Kadimij xikmatlar, қissalar. - Toshkent: Fafur Fulom nomidagi Adabijot va san\#at. nashrijoti. 1987. - pp.1640.

10. Stepanova EA (2011) Novaja duhovnost' i starye religii // Nauchno-teoreticheskij zhurnal «Religiovedenie». 2011. №1. -pp. 127-134.

11. Krymskij SB (1992) Kontury duhovnosti: Novye konteksty inlividual'nosti // Voprosy filosofii. 1992. №12. -pp. 213.

12. Bachinin VA (1986) Duhovnaja kul'tura lichnosti. Moscow, Politizdat, 1986. 